\title{
The Russian Arctic Sectoral Concept: Past And Present
}

\author{
LEONID TIMTCHENKO ${ }^{1}$
}

(Received 17 June 1996; accepted in revised form 16 October 1996)

\begin{abstract}
In 1907, Canadian Senator P. Poirier suggested dividing the Arctic into sectors belonging to the Arctic rim states. Canada in 1925 and the Soviet Union in 1926 established legislation based on this sectoral concept. The 1926 Decree of the USSR on the Arctic sector was interpreted in different ways by Soviet legal writers. State practice of the Soviet Union concerning the Arctic sector was more or less consistent. However, the attitude to the Arctic sector of the Russian Federation, as successor to the USSR in the North, is not quite clear. This article focuses on the doctrinal views and state practice of the Soviet Union and the Russian Federation relating to the sectoral concept.
\end{abstract}

Key words: Arctic, Russia, international law, sectoral concept

RÉSUMÉ. En 1907, le sénateur canadien P. Poirier a suggéré de diviser l'Arctique en secteurs qui appartiendraient aux États en bordure de l'Arctique. Le Canada, en 1925, puis l'Union Soviétique, en 1926, ont créé des lois qui s'appuyaient sur ce concept sectoriel. Le décret de l'URSS de 1926 sur le secteur arctique a été interprété différemment par les rédacteurs juridiques de l'Union Soviétique. La manière de procéder de cet État, en ce qui concerne le secteur arctique, a été plus ou moins cohérente. L'attitude de la Fédération de Russie (qui a succédé à l'URSS dans le Nord) envers le secteur arctique n'est cependant pas très claire. Cet article se penche sur les vues doctrinales et le protocole d'État de l'Union Soviétique et de la Fédération de Russie en ce qui a trait à ce concept sectoriel.

Mots clés: Arctique, Russie, droit international, concept sectoriel

Traduit pour la revue Arctic par Nésida Loyer.

\section{INTRODUCTION}

In 1907 Canadian Senator P. Poirier, to protect the rights of Canada in the Arctic, made a long speech in which he proposed the following:

a country whose possession today goes up to the Arctic regions will have a right, or should have a right, or has a right, to all the lands that are to be found in the waters between a line extending from its eastern extremity north, and another line extending from the western extremity north. All the lands between the two lines up to the North Pole should belong and do belong to the country whose territory abuts up there. (Canada, Senate Debates, 1907:271; cited in Pharand, 1988:10)

Thus, Senator Poirier put the first brick in the foundation of the concept of sectoral division of the Arctic. By that time, the Canadian Department of the Interior had already published two maps-Explorations in Northern Canada and Adjacent Portions of Greenland and Alaska (1904) and Atlas of Canada No.1, Territorial Divisions (1906) — that used the 141st and 60th meridians as the Canadian boundaries. The first map extended those boundaries up to the North Pole, the second one as far north as necessary to include all of the northernmost islands (Pharand, 1988). Nevertheless, Sir R.
Cartwright, the representative of the Canadian government in the Senate who got the floor after Poirier's speech, did not support the senator's sectoral initiative (Pharand, 1988). Later the Canadian government changed its position concerning the sectoral concept.

\section{LEGISLATION}

On 1 June 1925 the Canadian Parliament discussed an amendment to the Northwest Territories Act that required scientists and explorers who intended to work in the Northwest Territories to get licenses and permits. Minister of the Interior C. Stewart, who introduced the amendment in the Parliament, claimed Canadian sovereignty up to the North Pole (Pharand, 1988).

The adoption of the amendment had an interesting significance: it showed that until 1925, the Northwest Territories actually had been a territory for the common use, open to scientists and explorers from other countries.

On 19 July 1926 a Canadian order-in-council establishing the Arctic Islands Preserve was adopted, which used the sector configuration for the northern part of the Preserve. The same configuration was laid down in another order-in-council adopted on 15 May 1929, which introduced new game regulations (Pharand, 1988). 
The Soviet Union followed the Canadian path. On 15 April 1926 the Central Executive Committee of the USSR issued a Decree that stated:

All lands and islands, both discovered and which may be discovered in the future, which do not comprise at the time of publication of the present decree the territory of any foreign state recognized by the Government of the USSR, located in the northern Arctic Ocean, north of the shores of the Union of Soviet Socialist Republics up to the North Pole between the meridian $32^{\circ} 04^{\prime} 35^{\prime \prime} \mathrm{E}$. long. from Greenwich, running along the eastern side of Vaida Bay through the triangular marker on Cape Kekurskii, and the meridian $168^{\circ} 49^{\prime} 30^{\prime \prime} \mathrm{W}$. long. from Greenwich, bisecting the strait separating the Ratmanov and Kruzenstern Islands, of the Diomede group in the Bering Sea, are proclaimed to be territory of the USSR. (Butler, 1978:72; for the original text see Sobranie Zakonov SSSR, 1926)

The Decree referred directly to the sectoral concept and claimed only lands and islands inside the sector as Soviet territory. The eastern limit of the Soviet sector coincided with the demarcation line defined in the 1867 Boundary Treaty (Convention on ceding Alaska) between the United States and Russia (Pharand, 1988). The main aim of the 1867 Treaty was to define the limits of "the territory and dominion" ceded by Russia to the United States. The demarcation lines described in the Treaty were not state boundaries, but a cartographic device to simplify description of the lands concerned in the matter. The same idea constituted the purport of the Canadian legislation of 1925 and the Soviet decree of 1926 concerning the Arctic sectors. These acts aimed to prevent scientific and economic expansion by other states on lands and islands within the Arctic sector.

\section{DOCTRINAL VIEWS}

The tendency to spread sovereignty over polar territories emerged early in the 20th century as a reaction to the ongoing development of international scientific and economic activities there. The harshness of climatic conditions prompted some scientists to elaborate new concepts of acquiring territory so as to avoid the rules of effective occupation. Probably the most discussed among these concepts was the sectoral theory.

Soviet scientists provided the greatest support to the sectoral theory. The most cited among them is V.L. Lakhtine, who published in 1928 a monograph entitled Prava na severnye polyarnye prostranstva (Rights over the Arctic Regions). The author based his views on the Marxist-Leninist theory of the class struggle and the expansionist character of imperialism. He wrote: "The Soviet Union has considerable interests beyond the Arctic Circle that completely correspond to international law. In contrast to those of other countries, these interests are quite legal and determined by both strategic defence considerations, a wish to secure its northern coast from the possible offense of an enemy, and economic considerations" (Lakhtine, 1928:14-15). According to Lakhtine, these circumstances played the prime role in the adoption of the 1926 Decree.

In this case, what were the legal consequences of the sectoral division of the Arctic? Lakhtine considered that all lands and islands, both discovered and undiscovered, regardless of who effectively occupied them, had to be under the sovereignty of the owner of a sector in accordance with the principle of "rayona tyagoteniya" or "region of attraction." (The English version of this notion was given in Lakhtine, 1930:705). This principle is no more than a modification of the contiguity theory.

According to Lakhtine, undrifted ice should be equated to the land territory, i.e., be included in the sovereign part of a sectoral state. Drifted ice and ice-free waters, including territorial seas, had to be under the limited sovereignty of the northern coastal states (Lakhtine, 1928). With respect to air space, Lakhtine came to the conclusion that "the sovereignty of each sectoral state could be spread over air space above the whole sectoral region of its attraction" (Lakhtine, 1928:36). To strengthen his position, Lakhtine referred to Professor L. Breitfus, who was of the opinion that sovereignty by a northern state inside a sector spread over all spaces (Breitfus, 1927).

Lakhtine's position is rather controversial. He interpreted the provisions of the 1926 Decree quite broadly, including in the sphere of state sovereignty lands, islands, undrifted ice, and even the air space above a sector, i.e., above the high seas. Lakhtine repeatedly referred to international law but did not back up his position with any specific norms and principles of that law. Nevertheless, some Soviet legal scientists took his interpretation of the 1926 Decree as a point of departure for analyzing the legal regime of the Arctic, except for Lakhtine's viewpoint with respect to air space above a sector.

The first person to interpret the 1926 Decree in a broad sense was an international lawyer, E.A. Korovin. Answering a question about the limits of action of the 1926 Decree, Korovin (1926:46) insisted that the term "lands and islands" had to include also ice blocks and surrounding seas. This view was also shared by S.V. Sigrist (1928).

However, the legal adviser to the USSR People's Comissariat for Foreign Affairs, A. Sabanin, considered that the 1926 Decree showed the geographic coordinates inside which the Soviet Union claimed lands and islands, whether discovered or not. These demarcation lines did not mean borders for the polar sector and adoption of the sector theory (Butler, 1978).

The famous Soviet legal scientist E.B. Pashukanis did not refer to the sector concept while analyzing the legal regime of the Arctic. Nevertheless, he regarded as lawful the 1926 Decree, which was adopted "with the aim to form the northern borders of the USSR legally [and] precisely" 
(Pashukanis, 1935:127). Pashukanis wrote in particular: "the polar voyages of our icebreakers, the work of aviation, the opening up of the Northern Sea Route, the organization of the network of stations and settlements (on Franz Josef Land, Severnaya Zemlya, Wrangel Island, etc.), the great and systematic scientific work, all these facts [provide] evidence about rather effective occupation by the Soviet Union of the adjacent polar areas" (Pashukanis, 1935:127). He stressed the necessity of effective occupation for acquiring polar areas but not the sectoral theory. However, what the term "polar areas" means remained uncertain: was it land territories only, or land and sea spaces together, or something else?

V.N. Durdenevskiy (1950) considered that all Arctic states had accepted the sector theory and the necessity of creating sectors under the full sovereignty of the coastal states. V.I. Lisovskiy (1969) expressed the view that all polar states had a sector in the Arctic; but only islands within a sector were counted by him as territory of an Arctic state.

Authors of monographs and textbooks on international public law, and articles devoted to the legal regime of the Arctic published in the USSR in the 1960s, 1970s, and early 1980 s, adhered to similar views: i.e., all Arctic states had a sector. Further opinions divided mainly into two groups: a) only islands were territory of a coastal Arctic state (Kozhevnikov, 1964; Zhudro, 1964; Barabolya et al., 1966; Ignatenko and Ostapenko, 1978; Modzhoryan and Blatova, 1979; Tunkin, 1982, 1986); b) both lands and seas were under the sovereignty of an Arctic state (cf. Uustal, 1958). Zhudro (1964:99) considers in part that "the demarcation lines of the sectors are not state boundaries as some reckon. That is why a polar sector established by one or another state does not determine a question about the legal regime of the seas inside it."

The broad interpretation of the 1926 Decree on the part of many Soviet authors was connected with their desire to follow the Marxist-Leninist theory rather than the generally accepted principles and norms of international law. This theory stresses the expansionist character of imperialist states and the necessity for socialist states to resist this trend.

After the Soviet Union signed the UN Convention on the Law of the Sea (CLOS) in 1982, Soviet jurists began to depart from the Marxist-Leninist theory and rigid political schemes in their explanation of the institutions and norms of this branch of international law, adjusting their views in accordance with generally accepted principles. This process went ahead rapidly during the perestroika, but not without contradictions.

For example, B.M. Klimenko (1987) pointed out in 1987 that only islands and archipelagos within the limits of a sector belonged to a coastal state, being a part of its state territory. The legal regime of the sea expanses is instead determined by the norms and principles of the law of the sea, which may be modified according to the special conditions of the region.
However, a year later V.N. Kulebyakin (1988) in a textbook entitled Mezhdunarodnoe morskoe pravo (International Maritime Law), using strong political clichés, cited Korovin and argued that the sectoral states had rights in the Arctic over both land and sea territories. He considered that the Arctic sea expanses, because of their special character, could not be regarded in the same manner as other sea expanses. To strengthen his position, Kulebyakin (1988:143) also referred to the provisions of Article 234 of the UN Convention on the Law of the Sea. This rather controversial article gives coastal states the right to adopt and enforce nondiscriminatory laws and regulations for the prevention, reduction, and control of marine pollution from vessels in ice-covered areas within the limits of their exclusive economic zones (EEZs). But it is doubtful that this article and the CLOS as a whole contain legal grounds for the sectoral concept. Kulebyakin's arguments probably reflect the inertia of the old style of thinking rather than the real trends in the development of Soviet legal science.

The most distinctive feature of these trends, which are still in progress, is a desire to reevaluate many legal concepts on objective juridical grounds without help of the rigid Marxist-Leninist political formulae. A few examples will serve to illustrate this tendency. R.V. Vartanov and A.Yu. Roginko wrote in 1990: "Today there is an apparent need to define more precisely the correlation of the sectoral principle with the provisions of the contemporary law of the sea and to reconsider radically the approach to the whole international legal regime of the Arctic" (Vartanov and Roginko, 1990:70). It should be noted that the publications by Molodtsov (1987), Bekyashev et al. (1990), and Vereshchetin (1992) contained no mention of the Arctic sectoral concept. In a recent textbook on international law, there is not even a chapter or paragraph devoted to the Arctic (Kolosov and Kuznetsov, 1994). Vinogradov (1994) does mention the Arctic but with respect to the sectoral concept he states: "The controversial practice of states does not permit [us] to speak of a norm of the customary law formed on the basis of the sectoral theory. In this connection the "narrow" interpretation is preferable, according to which the sovereignty of a coastal state may be spread only over lands and islands but not over the whole Arctic space adjacent to the shore of the respective state" (Vinogradov, 1994:380).

These examples indicate that the Soviet/Russian science of international law is in the process of reevaluating the sectoral concept; the jurists trying to be guided by the generally accepted principles and norms of international law rather than by political considerations and schemes.

There is no uniformity concerning the sectoral concept among western legal writers either. The famous French international lawyer P. Fauchille differentiated between régions arctiques and régions polaires: effective occupation could be used to claim sovereignty over régions arctiques, situated along the Arctic Circle. Régions polaires, in the central part of the Arctic, consisted of ice 
and therefore were not suitable for settlement, but only for exploration. This meant that annexation of régions polaires was not possible. According to Fauchille (1925), these territories should be in the common possession of all nations interested in them. Fauchille suggested dividing the régions polaires among continents on a sectoral basis for their joint exploration on the part of states of each continent. He was against the sectoral division of the Arctic among the circumpolar states only (Fauchille, 1925).

The American jurist D.H. Miller thought that the sectoral division of the Arctic between the three great northern states, Canada, the United States, and the Soviet Union, would be very convenient. According to him, the legal basis for it could be found in the 1825 Russian-British Treaty about the Bering Sea and the 1867 Russian-American Treaty about the sale of Alaska. Miller (1925:54) referred to the "hinterland" theory or "territorial propinquity."

In 1926, a British international lawyer, M.F. Lindley, analyzed the correlation between the sector theory and hinterland theory. The latter appeared in connection with the discovery of coastal areas in Africa and claiming their hinterlands. He concluded that simple geographic contiguity was not a sort of legal right; however, this factor might have important political consequences; an international conference could accept the sectoral division in polar regions (Lindley, 1926:235).

The Norwegian author G. Smedal (1931:64) wrote: "The sector principle is not a legal principle having a title in the law of nations." He considered that a no-man's-land had to be acquired by occupation, or might be placed under the sovereignty of a single state in accordance with an international agreement.

A similar attitude to the sectoral theory was articulated by M.W. Mouton. He underlined that although the sectoral concept might be practical and convenient, it went "against all previously recognized methods of acquisition of territorial sovereignty, however relaxed with regard to Polar regions" (Mouton, 1963:243). Dr. Mouton criticized the principle of contiguity as a basic element of the sectoral concept, referring to the Island of Palmas arbitration of April 1928. To him, the sector theory is neither a generally accepted doctrine of international law nor a recognized method of acquisition of territorial sovereignty (Mouton, 1963).

Probably the most profound research on the sectoral theory was done by the authoritative Canadian international jurist, D. Pharand. He analyzed all aspects of the theory: its origin, boundary treaties, customary law, and contiguity as a basis for it. He arrived at the following conclusion: "The 1825 and 1867 boundary treaties cannot serve as a legal basis for the sector theory...Contiguity is incapable of serving as a legal basis for the sector theory...The sector theory has not developed as a principle of customary law" (Pharand, 1988:26, 43, 79). In other words, there are no legal grounds for the sectoral concept in the Arctic.
The above opinions lead us to conclude that doctrinal views concerning the sectoral concept differ greatly.

\section{STATE PRACTICE}

In contrast to the Soviet doctrinal views relating to the sector concept, state practice of the Soviet Union was rather consistent. First of all, it is necessary to underline that the USSR had never officially laid claim to the waters beyond the limits of national jurisdiction within its sector. The American practice of entering the Soviet sector with warships in 1957, 1963-65, and 1967 illustrates this well (Butler, 1978).

In 1937, the Soviet Union commenced its vast programme of using ice islands as drifting scientific stations. For decades, the ice stations crisscrossed the Arctic Ocean, entering the sectors of all Arctic states (Prokhorov, 1976). This circumstance proves that the USSR did not consider the limits of the Arctic sectors as state boundaries.

The negotiations between the Soviet Union (and now Russia) and Norway concerning the delimitation of the continental shelf and exclusive economic zones (EEZ) in the Barents Sea, in progress since 1974, are related to the sectoral concept. The Soviet Union insisted on the recognition of the sector concept as a special circumstance for the region, considering that the delimitation line should coincide with the western limit of the Soviet sector, i.e., the meridian 32 04'35" E. longitude (Molodtsov, 1982; Østreng, 1986).

The same position was taken by the USSR during the negotiations with the United States on a similar problem in the Chukchi Sea in 1980-90 (Ivanov, 1992). Unlike the Barents Sea case, the Soviet Union and the United States signed an agreement concerning the delimitation between them of the continental shelf and EEZs in the Chukchi and Bering Seas on 1 July 1990. The delimitation line in the Chukchi Sea coincides with the eastern limit of the Soviet sector. Article 1(1) of this agreement states: "The Parties agree that the line described as the 'western limit' in Article 1 of the 1867 Convention, as defined in Article 2 of this Agreement, is the maritime boundary between the United States and the Soviet Union" (International Legal Materials, 1990:941-945). It seems that the USSR used the sector lines in both cases as a convenient way to delimit the sea expanses in this region and take into consideration its economic and strategic interests.

On 1 October 1987 in Murmansk, the Soviet leader M.S. Gorbachev delivered a speech devoted chiefly to the problems of the Arctic and their solution (Pravda, 2 October 1986). The world's mass media called this speech "the Murmansk Initiative" of the Soviet Union because it contained a series of wide-ranging proposals for regional security and cooperation in the Arctic, which marked a real breakthrough in the Soviet approach to this region. For the first time in several decades, the USSR decided to lift the "iron curtain" over its Arctic areas and called for 
international cooperation in many fields in the North. The Murmansk initiative did not touch the Arctic sectoral concept directly, but it definitely influenced the process of seeking new approaches to this concept on the part of the Soviet state bodies and legal scientists.

Despite radical changes in Soviet political thinking during the perestroika, according to E. Franckx (1992), there were some doubts concerning the official Soviet position with respect to the Arctic sector. Franckx refers to the Annex to Issue 1 of the 1986 Notices to Mariners, which contained a chapter entitled "Legal Acts and Regulations of the USSR State Organs on Questions of Navigation." The chapter included the 1926 Decree "On the Proclamation of Lands and Islands Located in the Northern Arctic Ocean as Territory of the USSR." In this connection Franckx (1992:372) writes: "The inclusion of the sector decree in a maritime law context is somewhat unusual and even inappropriate, unless it is indicative of the fact that the sector still serves a purpose in Soviet maritime law."

It is rather difficult to agree with Franckx, because all lands and islands have a belt of territorial waters. In 1986 the Soviet Union controlled the navigation of foreign warships in its territorial seas. The main idea of publishing the 1926 Decree in the Annex to Issue 1 of the Notices to Mariners of 1986 was to focus attention on this circumstance - in other words, to defend Soviet national interests in the territorial waters of the Arctic islands. Nevertheless, Franckx is quite right about the lack of clarity in Soviet policy; even today, after the collapse of the USSR, the official position of its successor-the Russian Federation-relating to the sector concept is still not clear.

However, some recent events may indicate the attitude of the Russian Federation to the Arctic sectoral concept. For example, during incidents between Russian and American submarines off the Kola Peninsula in February 1992 and March 1993, Russian commentators did not refer to the sector theory, nor did the government use the theory in its response to the incidents (Komsomol'skaya pravda, 21 March 1992; Izvestiya, 23 March 1993). A letter of 16 October 1992 from V. Mikhaylichenko, Chief of the Administration of the Northern Sea Route, to Mr. Kuieken, Master of the motor vessel Solo, concerning the sailing of the Greenpeace vessel along seaways of the Northern Sea Route stated:

We would like to draw your attention to the fact that the Regulations for Navigation on the Seaways of the Northern Sea Route were officially published in Notices to Mariners No. 29 on July 13, 1991.

To obtain permission for the navigation of your vessel Solo along the seaways of the Northern Sea Route, you had to send a request to the Administration of the Northern Sea Route...

You would have obtained the permission for navigating along the Northern Sea Route, the date, the area of navigation, and the conditions of the ice pilotage after the expert examination of your vessel to define her correspondence to the Requirements for the Design, Equipment, and Supply of Vessels Navigating the Northern Sea Route.

Please note that the permission for navigating along the Northern Sea Route does not give the right to conduct any scientific research, tourism, or fishing in the Russian Arctic. For these purposes, you should send a request to the Ministry of Foreign Affairs of the Russian Federation.

Presently only the transit of foreign vessels along the Northern Sea Route is possible (or sailing to the port of Igarka), because the Russian Arctic ports (except Igarka) are not open to foreign vessels.

You entered the seaways of the Northern Sea Route without the mentioned permission, which was a violation of the Regulations for Navigation on the Seaways of the Northern Sea Route, in particular Regulations 3, 4, and 7. According to the Edict of the Presidium of the Supreme Soviet of the USSR of November 26, 1984 (which is still in force) "On the Strengthening of the Protection of Nature in the Extreme North and Marine Areas Adjacent to the Northern Coast of the USSR" and articles 3 and 14 (of this Edict) you may be fined. (The letter was obtained by the author from the Department of Merchant Marine of the Russian Ministry of Transport on 27 June 1995)

Note that there is no reference to the sectoral Decree of 1926 in this letter.

An article in Izvestiya was devoted to President Yeltsin's plan to organize principally new international routes in airspace above the North Pole and the Arctic Ocean, which had been tightly closed by the missile shield for decades. This article calls the 1926 Decree, which established "the polar possessions of the USSR" as "the famous funny paper" (Bocharov, 1995). Taking into consideration these facts, it is possible to conclude that a revision of the Arctic sector concept is occurring in Russian governmental structures as well.

It would be appropriate for the governments of Russia and Canada to clarify their attitude to the Arctic sectoral concept by political and legal means, taking into consideration new trends in the development of international relations in the world as a whole and in the Arctic in particular.

\section{SUMMARY}

Only two northern states, Canada and Russia (earlier the Soviet Union) rely on the sector concept in their state practice in the Arctic.

The position of Canada, the initiator of the Arctic sectoral concept, is rather controversial. On the one hand, there is much evidence of Canadian claims over only the Arctic islands on the grounds of the sector concept. On the 
other hand, sometimes Canada has tried to spread its rights over the sea expanses within the Canadian sector. The official attitude of Canada to this matter is not absolutely clear even now.

The Soviet Union in its 1926 Decree proclaimed only lands and islands in the limits of the Soviet sector as a part of state territory. The USSR took the delimitation line of the 1867 Boundary Treaty between the United States and Russia as the eastern limit of the Arctic sector. There was no evidence that the Soviet Union used the sector theory to spread its sovereignty over the sea areas. The Soviet Union (now Russia) has never considered the limits of the Arctic sector as national boundaries. Nevertheless, the eastern and western limits of the Soviet sector were used by the USSR at the negotiations with the United States and Norway concerning the delimitation of the continental shelf and EEZs. The western delimitation line of the 1867 Treaty was used to delimit the continental shelf and EEZs between the United States and the Soviet Union in the Chukchi Sea in the 1990 Soviet-American Agreement on the maritime boundary delimitation in the Chukchi and Bering Seas. In this connection, it is possible to conclude that the 1867 Treaty and the 1990 Agreement give some legal grounds for the sectoral concept. However, the basic element of the concept - the theory of contiguity-does not accord with international law. It seems that the Soviet Union used the sector lines at the negotiations with Norway and in the agreement with the United States as a convenient way to delimit the sea expanses.

In the 1920s, Canada and the Soviet Union adopted the sectoral acts in order to prevent economic and scientific expansion on the part of other states in the land areas adjacent to their northern coasts. According to Fogelson (1992:162), by 1930, despite the lack of recognition by the United States, "the Arctic was effectively divided into sectors extending around the Arctic Circle and encompassing an area from the subarctic to the North Pole."

The position relating to the sector concept of the successor to the Soviet Union in the Arctic, the Russian Federation, is not clear. There are some signs that Russia is reviewing this policy.

The establishment of sectoral legislation by the Soviet Union in the concrete historical circumstances of the 1920s was more or less understandable. However, the world has changed significantly since that period. Now the world needs cooperative rather than divided efforts of all states in political, economic, social, scientific, and ecological spheres to procure sustainable development in the Arctic. That is why it is necessary to revise and clarify the attitude of the Russian Federation (as well as Canada) to the sector concept, taking into consideration this aim.

\section{REFERENCES}

BARABOLYA, P.D., BAKHOV, A.S., IVANASHCHENKO, L.A., KOLESNIK, D.N., LOGUNOV, V.D., MOLODTSOV, S.V., and NASINOVSKIY, E.N. 1966. Voenno-morskoy mezhdunarono-pravovoy spravochnik [The Naval international law manual]. Moscow: Voenizdat.

BEKYASHEV, K.A., VOLKOV, A.A., and KARGOPOLOV, S.G., eds. 1990. Morskoe i rybolovnoe pravo [Maritime and fishery law]. Moscow: Agropromizdat.

BOCHAROV, G. 1995. Poruchenie Prezidenta. Kak i zachem budet otkryvat'sya nebo Rossii [An assignment of the President. How and for what the sky of Russia will be open]. Izvestiya. August 17.

BREITFUS, L. 1927. O razgranichenii severnoy polyarnoy oblasti [About delimitation of the northern polar region]. Morskoy sbornik 1:3-13.

BUTLER, W.E. 1978. International straits of the World: Northeast Arctic passage. Alphen aan Rijn: Sijthoff \& Noordhoff.

CANADA, SENATE DEBATES. 20 February 1907; as reprinted by Pharand, D., Canada's Arctic waters in international law. Cambridge, England: Cambridge University Press, 1988. 10.

DURDENEVSKIY, V.N. 1950. Problema pravovogo rezhima pripolyarnykh oblastey [A problem of the legal regime of the near-Polar regions]. Vestnik MGU 7:111-114.

FAUCHILLE, P. 1925. Traité de Droit International Public. Paris: Rousseau. Vol. 1, pt. 2.

FOGELSON, N. 1992. Arctic exploration and international relations 1900-1932. Fairbanks: University of Alaska Press.

FRANCKX, E. 1992. Nature protection in the Arctic: Recent Soviet legislation. International and Comparative Law Quarterly 41(2):366-386.

IGNATENKO, G.V., and OSTAPENKO, D.D., eds. 1978. Mezhdunarodnoe pravo [International law]. Moscow: Vysshaya shkola.

INTERNATIONAL LEGAL MATERIALS. 1990. Vol. 29. American Society of International Law.

IVANOV, S. 1992. Sindrom Alyaski [Syndrome of Alaska]. Komsomol'skaya pravda. February 4.

KLIMENKO, B.M. 1987. Pravovoy rezhim Arktiki [The legal regime of the Arctic]. In: Blatova, N.T., ed. Mezhdunarodnoe pravo [International law]. Moscow: Yuridicheskaya literatura.

KOLOSOV, Yu.M., and KUZNETSOV, V.I., eds. Mezhdunarodnoe pravo [International law]. Moscow: Mezhdunarodnye otnosheniya.

KOROVIN, E.A. 1926. SSSR i polyarnye zemli [The USSR and the Polar lands]. Sovetskoe pravo No. 3:43-46.

KOZHEVNIKOV, F.I., ed. 1964. Mezhdunarodnoe pravo [International law]. Moscow: Mezhdunarodnye otnosheniya.

KULEBYAKIN, V.N. 1988. Pravovoy rezhim Arktiki [The legal regime of the Arctic]. In: Blishchenko, I.P., ed. Mezhdunarodnoe morskoe pravo [International maritime law]. Moscow: Izdatel'stvo Universiteta druzhby narodov. 134-144.

LAKHTINE, V.L. 1928. Prava na severnye polyarnye prostranstva [Rights over the Arctic regions]. Moscow: Izdanie Litizdata Narodnogo Komissariata po Inostrannym Delam.

1930. Rights over the Arctic. The American Journal of International Law 24:703-717.

LINDLEY, M.F. 1926. The acquisition and government of backward territory in international law: Being a treatise on the law and practice relating to colonial expansion. London: Longmans, Green and Co. 
LISOVSKIY, V.I. 1969. Mezhdunarodnoe pravo [International law]. Moscow: Vysshaya shkola.

MILLER, D.H. 1925. Political rights in the Arctic. Foreign Affairs 4(1):47-60.

MODZHORYAN, L.A., and BLATOVA, N.T., eds. 1979. Mezhdunarodnoe pravo [International law]. Moscow: Yuridicheskaya literatura.

MOLODTSOV, S.V. 1982. Pravovoy rezhim morskikh vod [The legal regime of the sea waters]. Moscow: Mezhdunarodnye otnosheniya.

—. 1987. Mezhdunarodnoe morskoe pravo [International maritime law]. Moscow: Mezhdunarodnye otnosheniya.

MOUTON, M.W. 1963. The international regime of the polar regions. Recueil des Cours. 1962, III. Leyden: A.W.Sijthoff.

ØSTRENG, W. 1986. Norway in northern waters. In: Archer, C., and Scrivener, D., eds. Northern waters. London and Sydney: Croom Helm. 155-173.

PASHUKANIS, E. 1935. Ocherki po mezhdunarodnomu pravu [Essays on international law]. Moscow: Sovetskoe zakonodatel'stvo.

PHARAND, D. 1988. Canada's Arctic waters in international law. Cambridge: University Press.

PROKHOROV, A.M., ed. 1976. Bol'shaya sovetskaya entsiklopediya [The great Soviet encyclopedia]. Vol. 23. Moscow: Sovetskaya entsiklopediya.
SIGRIST, S.V. 1928. Sovetskoe pravo v polyarnykh prostransvakh [The Soviet law in the polar spaces]. Rabochiy sud 13:982-987.

SMEDAL, G. 1931. Acquisition of sovereignty over polar areas. Oslo: Jacob Dybwad.

SOBRANIE ZAKONOV SSSR. 1926. On the proclamation of lands and islands located in the northern Arctic Ocean as territory of the USSR. No. 32(203).

TUNKIN, G.I., ed. 1982. Mezhdunarodnoe pravo [International law]. Moscow: Yuridicheskaya literatura.

. 1986. International law. Moscow: Progress.

UUSTAL, A.T. 1958. Mezhdunarodno-pravovoy rezhim territorialnykh vod [The international law regime of territorial waters]. Tartu, Estonia: Uchenye zapiski Tartuskogo universiteta.

VARTANOV, R.V., and ROGINKO, A.Yu. 1990. New dimensions of Soviet Arctic policy: Views from the Soviet Union. Annals of the American Academy of Political and Social Sciences 512 (November):69-78.

VERESHCHETIN, V.S., ed. 1992. Kurs mezhdunarodnogo prava [Course of international law]. Vol. 5. Moscow: Nauka.

VINOGRADOV, S.V. 1994. Pravovoy rezhim Arktiki [The legal regime of the Arctic]. In: Tunkin, G.I., ed. Mezhadunarodnoe pravo [International law]. Moscow: Yuridicheskaya literatura. $378-382$.

ZHUDRO, A.K., ed. 1964. Morskoe pravo [Maritime law]. Moscow: Transport. 